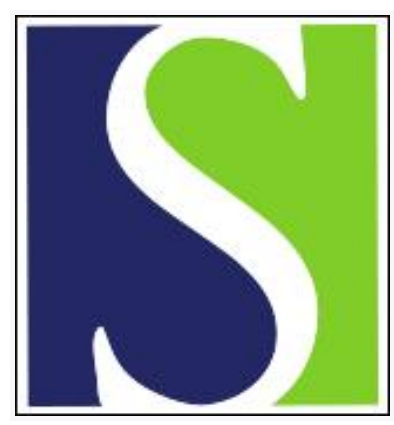

Scand J Work Environ Health 1999;25(2):125-130

https://doi.org/10.5271/sjweh.414

Issue date: Apr 1999

Etiologic clues to lip cancer from epidemiologic studies on farmers

by Khuder SA

The following article refers to this text: 2002;28 suppl 1:1-88

Key terms: infection; lip cancer; meta-analysis; occupation; sunlight

This article in PubMed: www.ncbi.nlm.nih.gov/pubmed/10360467

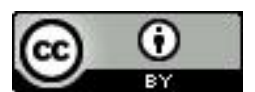




\title{
Etiologic clues to lip cancer from epidemiologic studies on farmers
}

\author{
by Sadik A Khuder, PhD'
}

\begin{abstract}
Khuder SA. Etiologic clues to lip cancer from epidemiologic studies on farmers. Scand $J$ Work Environ Health 1999;25(2):125-130.

Objectives This study examined the risk factors for lip cancer among farmers. Methods A series of meta-analyses of peer-reviewed studies of lip cancer and farming were performed using 21 studies published between 1981 and 1997. Prior to the meta-analyses, all the studies were reviewed and evaluated for heterogeneity and publication bias. Combined relative risks (RR) were calculated using the random effect model.

Results The combined RR for lip cancer was 2.0 [95\% confidence interval ( $95 \% \mathrm{CI}) 1.74-2.30$ ] for all the studies and 1.28 (95\% CI 0.79-2.08) for studies involving female farmers. Additional meta-analyses were undertaken on a subset of studies reporting on skin cancer among farmers. The combined RR for nonmelanotic skin cancer was 1.0 (95\% Cl 0.89-1.14), and for malignant melanoma it was 0.88 (95\% CI 0.74-1.05).

Conclusions The findings suggest that male farmers have a significantly elevated risk for lip cancer. Lip cancer and skin cancer do not share a common etiologic factor. Besides sunlight exposure, other factors such as viral infection or reduced immunity may play a role in the etiology of lip cancer.
\end{abstract}

Key terms infection, lip cancer, meta-analyses, occupation, sunlight.

Lip carcinoma accounts for nearly $25 \%$ of all oral cancer cases, and in some countries it is the most common site for oral cancer to occur (1). International data show that lip cancer is primarily a disease of aging white men, with Newfoundland having extremely elevated rates while in Switzerland and Japan the occurrence of the disease is negligible (2)

Lip cancer has long been considered to be causally associated with tobacco smoking and prolonged exposure to sun light (3). However, several investigators have questioned this long-held belief. Several investigators have reported data which are inconsistent with the actinic radiation or smoking hypothesis. Lip cancer is more common in rural than in urban areas (4), and higher rates have been reported for outdoor occupations such as farming, fishing, and forestry (5). Because of the great occupational stability, farmers are a group uniquely suited for assessing the potential contribution of a given exposure to the occurrence of a disease. Since farmers' prevalence of smoking is less than that of the general population (6) excess lip cancer in this group suggests that the relative contribution of smoking to the occurrence of the disease is minimal. Since farmers experience lifelong sunlight exposure, assessing the contribution of sunlight to the occurrence of the disease can be accomplished by examining the association between lip cancer and farming. In this study, a series of meta-analyses of peer-reviewed studies of lip cancer and farming was performed and evaluated in the context of study design and exposures that are associated with the disease and are experienced by farmers.

\section{Material and methods}

The Medical Abstract and Cancer Abstracts databases were searched for articles about farming and lip cancer. The search of MEDLINE data was from 1981 until 31 December 1997. The Cancer Abstracts database search included articles published from 1980 until 31 December 1997. References cited in the studies found by examining the 2 data bases were also included in the metaanalyses. Articles were excluded from the analyses for any one of the following reasons: (i) occupations other than farming were included in the definition of exposure and no data specific to farmers were published, (ii) insufficient data for determining an estimator of relative risk or a confidence interval were published, (iii) the

Reprint requests to: Dr SA Khuder, Medical College of Ohio, PO Box 10008, Toledo, OH 43699-0008, USA. [E-mail: skhuder@mco.edu] 
group studied was included in another study of similar design examining a greater number of subjects, (iv) the disease studied was not specifically designated as lip cancer or lip cancer was included with other oral cancers.

The remaining articles were then examined and estimators of the relative risks (RR) were extracted. The RR estimators were odd ratios (OR) for case-referent studies, standardized incidence ratios (SIR) for cohort studies, and proportional mortality ratios (PMR) for mortality studies.

Once the studies had been selected, a series of metaanalyses was conducted, and the results were evaluated in the context of the published literature. The homogeneity of the estimators of relative risk was tested using Cochran's Q statistics (7). This is a chi-square test with degrees of freedom equal to the number of studies minus one. It tests the null hypothesis that the within-study estimates of relative risk are homogeneous across studies. Significant heterogeneity was detected within the groups of studies; therefore, the random effects model (8) was used to obtain the combined RR and its standard error (SE).

The first meta-analysis examined all studies that met the criteria for inclusion. A second meta-analysis was restricted to female farmers (studies reporting on farmers who were female or female relatives of farmers who assisted in farming). Additional meta-analyses were conducted for subsets of studies that reported skin cancer (malignant melanoma and nonmelanotic skin cancer).

The relation between the estimator of relative risk and study size was explored by plotting the natural logarithm of the estimator of relative risk ( $\ln \mathrm{RR}$ ) versus the inverse of the standard error (1/SE). An adjusted rank correlation test (9) was used to test for potential bias due to study size. The absence of significant correlation acted to reassure that the studies had been selected in an unbiased manner.

\section{Results}

Twenty-four studies examining the association between farming and lip cancer were identified. Two studies (5, 10 ) were excluded from the analyses because the exposures examined were not specifically limited to farmers. One study (11) was excluded because of insufficient data to calculate relative risk. The remaining 21 studies are listed in table 1.

Most of the studies included in the analyses were restricted to whites and male farmers. One study (12) was restricted to women, and 4 studies provided data for female farmers (table 2). Nine studies provided data on malignant melanoma and nonmelanotic skin cancer (table 3). Out of the 21 studies included, 17 studies reported a significant positive association between lip cancer and farming, and 3 studies reported a nonsignificant association. The estimator of relative risk ranged from 1.30 to 5.30. The estimator of relative risk for skin cancer ranged from 0.42 to 1.29 for malignant melanoma and from 0.69 to 1.50 for nonmelanotic skin cancer. A plot of $\ln \mathrm{RR}$ versus $1 / \mathrm{SE}$ showed no relation between

Table 1. Description of the studies included in the meta-analysis of lip cancer and farming

\begin{tabular}{|c|c|c|c|c|c|c|}
\hline Reference & Country & Study period & Method & $\begin{array}{c}\text { Exposed } \\
\text { cases }\end{array}$ & $\begin{array}{c}\text { Relative } \\
\text { risk }\end{array}$ & $95 \% \mathrm{Cl}$ \\
\hline \multicolumn{7}{|l|}{ Cohort studies } \\
\hline Wiklund \& Dich, 1994 (12) & Sweden & $1971-1987$ & Census & 7 & 0.94 & $0.38-1.93$ \\
\hline Kristensen et al, $1996(41)$ & Norway & $1969-1989$ & Agriculture census & 41 & 1.40 & $1.03-1.91$ \\
\hline Ronco et al, $1992(13)$ & Denmark & $1970-1980$ & Cancer register & 225 & 1.85 & $1.63-2.11$ \\
\hline Wiklund \& Dich, 1995 (14) & Sweden & $1971-1987$ & Census & 392 & 2.00 & $1.81-2.21$ \\
\hline Gunnarsdottir \& Rafnsson,1991 (15) & Iceland & $1977-1987$ & Farmer pension & 9 & 1.83 & $0.85-3.96$ \\
\hline Pukkala \& Notkola,1997 (32) & Finland & $1979-1993$ & Farmer register & 367 & 1.48 & $1.34-1.64$ \\
\hline Stark et al, $1990(16)$ & United States & $1973-1983$ & Farm bureau & 7 & 1.70 & $0.81-3.57$ \\
\hline Pukkala et al, 1994 (45) & Finland & $1971-1985$ & Gensus & 433 & 1.46 & $1.33-1.61$ \\
\hline Lynch \& Thygesen, 1990 (17) & Denmark & $1970-1980$ & Census & 182 & 1.80 & $1.55-2.08$ \\
\hline \multicolumn{7}{|l|}{ Mortality and morbidity studies } \\
\hline Wiklund, $1983(18)$ & Sweden & $1961-1973$ & Census data & 508 & 1.83 & $1.65-2.03$ \\
\hline Blair et al, 1993 (19) & United States & $1984-1988$ & Death certificate & 22 & 2.40 & $1.53-3.75$ \\
\hline Burmeister, 1981 (20) & United States & $1971-1978$ & Death certificate & 20 & 1.62 & $1.05-2.51$ \\
\hline Gallagher et al, 1984 (21) & Canada & $1950-1978$ & Death certificate & 17 & 1.91 & $1.11-3.06$ \\
\hline \multicolumn{7}{|l|}{ Case-referent studies } \\
\hline Keller \& Howe, 1994 (46) & United States & $1986-1988$ & Medical record & 11 & 4.42 & $2.46-7.94$ \\
\hline Fincham et al, $1992(31)$ & Canada & $1983-1989$ & Questionnaire & 46 & 2.52 & $1.71-3.72$ \\
\hline Reif et al, 1989 (42) & New Zealand & $1980-1984$ & Cancer register & 59 & 2.43 & $1.81-3.27$ \\
\hline Franceschi et al, 1993 (22) & Italy & $1985-1991$ & Interview & 6 & 1.30 & $0.50-3.80$ \\
\hline Brownson et al, 1989 (23) & United States & $1984-1988$ & Medical record & 34 & 3.07 & $1.99-4.73$ \\
\hline Spinelli et al, $1990(24)$ & Canada & $1950-1975$ & Medical record & 121 & 2.50 & $2.00-3.20$ \\
\hline Haguenoer et al, 1990 (25) & France & $1983-1983$ & Interview & 6 & 5.30 & $2.38-11.8$ \\
\hline Dardanoni et al, 1984 (26) & Italy & $1980-1982$ & Questionnaire & 27 & 2.63 & $1.80-3.84$ \\
\hline
\end{tabular}


relative risk and study size (figure 1 ). The test for publication bias indicated no evidence of bias due to study size $(\mathrm{P}=0.95)$.

The meta-analysis including all studies yielded a combined RR of 2.0 [95\% confidence interval $(95 \% \mathrm{CI})$ $1.74-2.30]$. The estimator of relative risk for female farmers was 1.28 (95\% CI $0.79-2.08)$.

The meta-analysis for the studies reporting on skin cancer yielded a combined RR of $0.88(95 \%$ CI $0.74-$ 1.05 ) for malignant melanoma and $1.0(95 \%$ CI $0.89-$ 1.14) for nonmelanotic skin cancer. The combined estimate for lip cancer in these studies was 2.0 (95\% CI $1.71-2.34)$.

\section{Discussion}

This study attempted to investigate the epidemiologic characteristics of lip cancer in farmers and to determine the degree to which known risk factors influenced the prevalence. The significant association between lip cancer and farming resulting from the meta-analysis of the 21 selected studies suggests that farming is a risk factor for the disease. This finding is in agreement with the results of other meta-analyses of farming and cancer $(27$, 28). The preponderance of significant positive studies among the studies with the greatest number of subjects also supports an association between lip cancer and farming. However, the insignificant association between

Table 2. Relative risks and $95 \%$ confidence intervals from studies of lip cancer among female farmers.

\begin{tabular}{lrrr}
\hline Reference & $\begin{array}{c}\text { Exposed } \\
\text { cases }\end{array}$ & $\begin{array}{c}\text { Relative } \\
\text { risk }\end{array}$ & $95 \% \mathrm{Cl}$ \\
\hline Wiklund \& Dich, 1994 (12) & 7 & 0.94 & $0.38-1.93$ \\
Kristensen et al, 1996 (41) & 2 & 2.78 & $0.28-8.58$ \\
Pukkala \& Notkola, 1997 (32) & 18 & 0.95 & $0.56-1.49$ \\
Pukkala et al, 1994 (45) & 10 & 1.67 & $0.80-3.07$ \\
Blair et al, 1993 (19) & 1 & 12.20 & $0.16-68.0$ \\
\hline Combined & 38 & 1.28 & $0.79-2.08$ \\
\hline
\end{tabular}

Table 3. Skin cancer and malignant melanoma for studies included in the meta-analysis.

\begin{tabular}{|c|c|c|c|c|c|c|}
\hline \multirow[t]{2}{*}{ Reference } & \multicolumn{3}{|c|}{ Skin cancer } & \multicolumn{3}{|c|}{ Malignant melanoma } \\
\hline & $\begin{array}{c}\text { Exposed } \\
\text { cases }\end{array}$ & $\begin{array}{l}\text { Relative } \\
\text { risk }\end{array}$ & $95 \% \mathrm{Cl}$ & $\begin{array}{c}\text { Exposed } \\
\text { cases }\end{array}$ & $\begin{array}{l}\text { Relative } \\
\text { risk }\end{array}$ & $95 \% \mathrm{Cl}$ \\
\hline Kristensen et al, 1996 (41) & 40 & 0.89 & $0.64-1.19$ & 123 & 0.83 & $0.69-0.98$ \\
\hline Ronco et al, $1992(13)$ & 591 & 0.69 & $0.64-0.75$ & 89 & 0.66 & $0.54-0.82$ \\
\hline Wiklund \& Dich, 1995 (14) & 676 & 0.98 & $0.91-1.06$ & 327 & 0.79 & $0.71-0.88$ \\
\hline Gunnarsdottir \& Rafnsson, 1991 (15) & 9 & 1.50 & $0.78-2.88$ & 2 & 0.50 & $0.13-2.00$ \\
\hline Pukkala \& Notkola,1997 (32) & 400 & 1.09 & $0.98-1.19$ & 330 & 1.12 & $1.00-1.24$ \\
\hline Stark et al, $1990(16)$ & - & - & - & 18 & 1.02 & $0.64-1.62$ \\
\hline Wiklund, $1983(18)$ & 708 & 1.09 & $1.01-1.17$ & 268 & 0.82 & $0.73-0.92$ \\
\hline Blair et al, $1993(19)$ & 425 & 1.07 & $0.97-1.18$ & 244 & 0.95 & $0.83-1.07$ \\
\hline Burmeister, 1981 (20) & 105 & 1.13 & $0.93-1.39$ & - & . & - \\
\hline Keller \& Howe, 1994 (46) & - & - & - & 41 & 1.29 & $0.77-2.14$ \\
\hline Fincham et al, 1992 (31) & 94 & 1.13 & $0.90-1.41$ & 24 & 0.42 & $0.27-0.64$ \\
\hline Reif et al, $1989(42)$ & - & - & - & 166 & 1.25 & $1.05-1.50$ \\
\hline Brownson et al, 1989 (23) & - & - & - & 11 & 1.26 & $0.63-2.45$ \\
\hline Combined & 3038 & 1.00 & $0.89-1.14$ & 1643 & 0.88 & $0.74-1.05$ \\
\hline
\end{tabular}

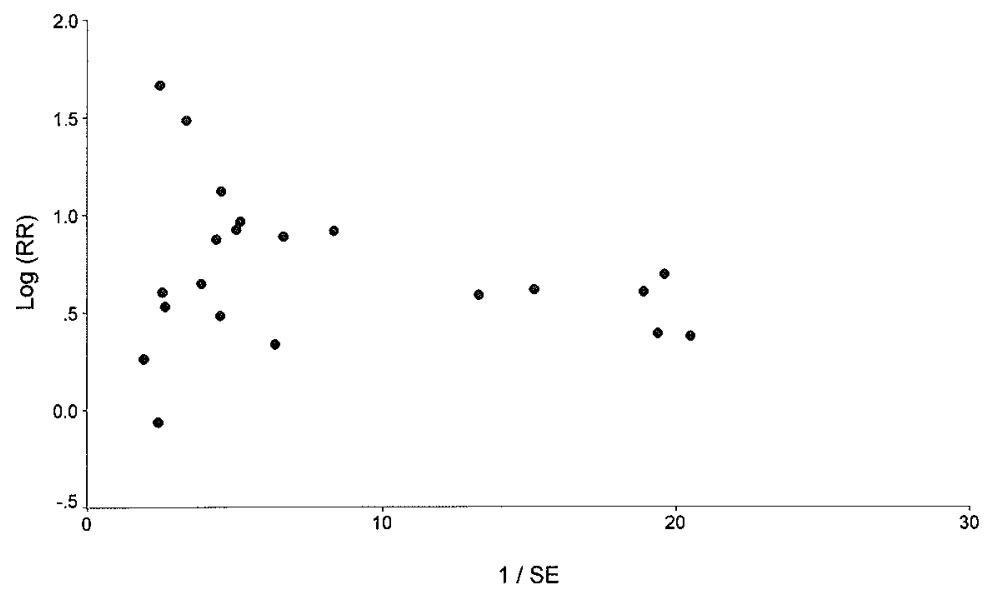

Figure 1. Relationship between the estimator of relative risk and study size in meta-analyses of lip cancer and farming. 
exposure and the disease produced by the meta-analysis limited to female farmers does not support an association between farming and lip cancer. This finding suggests that the women's exposures were significantly lower than those of the men's. Many studies report that male exposure to sunlight is higher than female exposure. A possible explanation for this gender difference is that outdoor farming activities are to a large degree carried out usually by the male farmer on a tractor. However, this practice may not be that important if the induction time is several decades, which might be true considering the old age of most persons with lip cancer. Furthermore, it is likely that the women worked actively outdoors in some types of farming earlier, at least in some countries. It has been hypothesized that the protection both from the sun and from chapping which is afforded by lipstick or other lip covering could account for the much lower lip cancer rate for women (29).

The majority of studies examined in this meta-analysis attributed the significant increase in lip cancer among farmers to their outdoor work and, more specifically, to sunlight exposure. However, none of the studies utilized a direct measure of solar exposure. In the literature, the bulk of evidence that implicates sunlight as an etiologic factor for lip cancer is based on analyses using indirect measures of solar exposure, such as residence, outdoor occupation, or an association of lip cancer with other types of cancers, known to be affected by sunlight (2). The majority of lip cancer is squamous cell carcinoma, and therefore the simultaneous occurrence of squamous cell cancer in multiple sites of the body has been assumed to suggest a common exposure. The high occurrence of multiple primary cancers of the lip and skin (11) have been used as support for the actinic radiation lip cancer hypothesis. In the present study, lip cancer was compared with skin cancer to determine the effect of sunlight on these diseases. Exposure to ultraviolet radiation in sunlight is a well documented major risk for skin cancer (30). In the present study, the meta-analyses of substudies revealed an insignificant association between farming and skin cancer (melanotic and nonmelanotic). This finding suggests that lip cancer and skin cancer do not share a common etiologic factor. The epidemiologic profile of lip cancer differs substantially from that of skin cancer in the same population and within the same period. The results of this study support the notion that different etiologic factors are involved in the development of lip cancer versus those involved in skin cancer. Sunlight is not the sole risk factor for lip cancer, and exposures other than ultraviolet light from the sun may be associated with the disease. Fincham et al (31) noted that the excess of lip cancer among farmers and a deficit of malignant melanoma can be accounted for by the evidence that lip cancer is positively associated with cumulative chronic doses of ultraviolet light, whereas malignant melanoma appears to be positively associated with short but intense sun exposure and may be inversely related to chronic low exposure. Sun bathing, for example, not usually practiced by farmers, is a major risk factor for skin cancer and not associated with lip cancer (10). It is possible that chronic exposure to sunlight protects against malignant melanoma by increasing melanin production or strengthening the immune system (31). Sunlight exposure from outdoor work might not be the most decisive factor involved in the etiology of lip cancer. It is possible that there is a synergistic effect of sunlight with other etiologic factors. Besides sun exposures, other factors causing dryness of the lips, such as dust, wind, lengthy period of outdoor work, might be involved in the etiology of the disease.

Farmers are exposed to, or come in contact with, several potentially hazardous chemicals and biological agents, including pesticides, solvents, fuels, dust, and zoonotic viruses (32). Chemical compounds such as organochlorine, organophosphates, arsenic, psoralen, and polycyclic aromatic hydrocarbons are widely used in agriculture. Many of these compounds are known or suspected as carcinogens. In vitro studies support the notion of a close relationship between exposure to environmental chemical carcinogens and the occurrence of $\mathrm{H}$ ras oncogene mutations in squamous cell carcinoma of lip vermilion (33). In a cohort study, an excess of lip cancer was reported in association with exposure to chlorine gas, hydrochlorine aerosols, chlorinated aromatics, and sulfur dioxide (34). Moreover, an excess of lip cancer has been reported for oil refinery workers (35), pharmaceutical workers (36), creosote-exposed workers (37), and workers exposed to engine exhaust (38). The reported excess of lip cancer among these industrial workers adds some evidence to the possibility that agricultural chemicals may play a role in the etiology of lip cancer. However, it is possible that a large proportion of the industrial workers was comprised, in fact, of part-time farmers or workers who had given up farming for industrial work.

Viral infection is a possible risk factor for lip cancer. A positive relationship has been noted between squamous cell carcinoma of the lip in mice and sequential exposure to the virus HSV-2, ultraviolet radiation, and a tumor-promoting chemical agent. However, Cassai et al (39) found no difference in virus susceptibility between human tumor cells and normal human cells cultured in vitro. Since exposure to cattle is associated with numerous infectious diseases (40), farmers who produce beef or milk are at risk for infectious diseases, and this factor may have contributed to an excess of lip cancer. Kristensen et al (41) found a significant association between lip cancer and exposure to animal farming. Lip cancer has been associated with dairy farming in New Zealand (42). Pukkala \& Notkola (32) noted that small dairy 
farmers had a significantly elevated risk for lip cancer. However, they noted that farmers having many cows or pigs had a lower risk of lip cancer than farmers in general.

Tobacco use is considered to increase the risk of tumor induction. Although smoking has been clearly demonstrated as a risk factor for oral cancer in general, its relative importance in lip cancer is not clearly defined (2). Keller (11) found an association between lip cancer and all types of tobacco consumption. On the other hand, Spitzer et al (43) found no relation between lip cancer and use of tobacco. It has been hypothesized that smokers experiencing recurrent herpes simplex virus (HSV1) infections are more liable to tumor initiation (44). Pukkala et al (45) indicated that the joint influence of outdoor work and smoking on the risk of lip cancer seems to be so strong that other possible risk factors may not be detected. Among the studies included in this metaanalysis, only two $(31,46)$ adjusted for cigarette smoking. The majority of studies indicated that the prevalence of cigarette smoking among farmers is lower than among the general population. However, the prevalence of other forms of tobacco consumption (such as tobacco chewing, pipe smoking) by male farmers may not differ from that of the general population, at least in some countries.

Lip cancer, like many other farm-related cancers, can be considered immune-related since the risk is strongly increased among immunosuppressed patients (40). The occurrence of lip cancer among patients with naturally and medically induced immunosuppression suggests that the high rates among farmers may be due to factors that affect the immune system (47). There may be factors in the agricultural environment that induce immune system deficiencies (40). Exposure to pesticides or organic dust of animal or plant origin may have resulted in decreased immunocompetence and therefore may have increased the occurrence of the disease. Reduced immunity could be a normal process possibly related to aging since most lip cancer cases are reported for older age farmers.

A deficiency of melanin pigment has also been suggested as a risk factor for lip cancer. Support for this hypothesis stems from the relative lack of the disease in dark-skinned people (1). Similarly, white persons with a ruddy or fair complexion have made up a large proportion of the farmers with lip cancer.

\section{Concluding remarks}

In conclusion, this study found a significant elevation in the risk of lip cancer among male farmers. The lack of association between skin cancer and farming suggests that sunlight is not the major risk factor for lip cancer. Further studies simultaneously examining other risk factors are indicated. Farmers' exposures to multiple risk factors, including sunlight, infectious microorganisms, and agricultural chemicals, make it plausible that an association between lip cancer and farming actually exists. The role of sunlight as a risk factor for lip cancer needs re-evaluation, and its relative importance as an etiologic agent or carcinogen needs to be better defined. More studies are needed to explore the gender differences in the relative risk of lip cancer in farmers.

\section{References}

1. Muir C, Waterhouse J, Mack T, Powell J, Whelan S, editors Cancer incidence in five continents. Lyon: International Agency for Research on Cancer (IARC), 1987. IARC Scientific Publication, vol V, no 88.

2. Douglas $\mathrm{CW}$, Gammon MD. Reassessing the epidemiology of lip cancer. Oral Surg 1984;57:631-42.

3. Lindqvist C. Risk factors in lip cancer: a questionnaire survey. Am J Epidemiol 1979;109:521-30.

4. Doll R. Urban and rural factors in the etiology of cancer. Int $\mathrm{J}$ Cancer 1991; 47:803-10.

5. MacFarlane GJ, Boyle P, Evstifeeva T, Scully C. Epidemiological aspects of lip cancer in Scotland. Community Dent Oral epidemiol 1993;21:279-82.

6. Pomrehn PR, Wallace RB, Burmeister LF. Ischemic heart disease mortality in Iowa farmers: the influence of life-style. JAMA 1982;248:1073-6.

7. Cochran WG. The combination of estimates from different experiments. Biometrics 1954;8:101-29.

8. DerSimonian R, Laird N. Meta-analysis in clinical trials. Control Clin Trials 1987;7:177-88.

9. Begg CB, Mazumdar M. Operating characteristics of rank correlation test for publication bias. Biometrics 1994;50:1088-101.

10. Lindqvist C, Teppo L, Pukkala E. Occupations with low risk of lip cancer show high risk of skin cancer of the head. Comm Dent Oral Epidemiol 1981;9:247-50.

11. Keller AZ. Cellular types, survival, race, nativity, occupations, habits and associated diseases in the pathogenesis of lip cancers. Am J Epidemiol 1970;91:486-99.

12. Wiklund $\mathrm{K}$, Dich $\mathrm{J}$, Cancer risks among female farmers in Sweden. Cancer Cause Cont 1994;5:449-57.

13. Ronco $\mathrm{G}$, Costa $\mathrm{G}$, Lynge E. Caner risk among Danish and Italian farmers. Br J Ind Med 1992;49:220-225.

14. Wiklund $\mathrm{K}$, Dich J. Cancer risks among male farmers in Sweden. Eur J Cancer Prev 1995;4:81—90.

15. Gunnarsdottir $\mathbf{H}$, Rafnsson $\mathrm{V}$. Cancer incidence among Icelandic farmers 1977-1987. Scand J Soc Med 1991;19:170-3.

16. Stark AD, Chang HG, Fitzgerald EF, Riccardi K, Stone RR. A retrospective cohort study of Cancer incidence among New York State Farm Bureau members. Arch Environ Health 1990;45:155-62.

17. Lynge E, Thygesen L. Occupational cancer in Denmark: cancer incidene in the 1970 census population. Scand J Work Environ Health 1990;16 suppl 2:1-35.

18. Wiklund K. Swedish agricultural workers: a group with a decreased risk of cancer. Cancer 1983;51:566-8.

19. Blair A, Dosemeci M, Heineman EF. Cancer and other causes of death among male and female farmers from twenty-three 
states. Am J Ind Med 1993;23:729-42.

20. Burmeister LF, Everett GD, Van Lier SF, Isacson P. Selected cancer mortality and farm practices in Iowa. Am J Epidemiol 1983;118:72-7.

21. Gallagher RP, Threlfall WJ, Jeffries E, Band PR, Spinelli J, Coldman AJ. Cancer and aplastic anemia in British Columbia farmers. JNCI 1984;72:1311-5.

22. Franceschi S, Barbone F, Bidoli E, Guarneri S, Serrainao D, Talamini R. Cancer risk in farmers: results from a multi-site case-control study in North-eastern Italy. Int J Cancer 1993;53:740-5

23. Brownson RC, Reif JS, Chang JC, Davis JR. Cancer risks among Missouri farmers. Cancer 1989;64:2381-6.

24. Spinelli JJ, Gallagher RP, Band PR, Threlfall WJ, Raynor D, Schellekens H. Occupational associations among British Columbia male cancer patients. Can J Public Health 1990;81:254-8

25. Haguenoer JM, Cordier S, Morel C, Lefebvr JL, Hemon D. Occupational risk factors for upper respiratory tract and upper digestive tract cancers. Br J Ind Med 1990;47:380-3.

26. Dardanoni L, Gafà L, Paternò R, Pavone G. A case-control study on lip cancer risk factors in Ragusa (Sicily). Int J Cancer 1984;34:335-7.

27. Blair A, Hoar Zahm S, Pearce NE, Heineman EF, Fraumeni JF Jr. Clues to cancer etiology from studies of farmers. Scand J Work Environ Health 1992;18:209-15.

28. Acquavella J, Olsen G, Cole P, Ireland B, Kaneene J, Schuman S, Holden L. Cancer among farmers: a meta-analysis. Ann Epidemiol 1998;8:64-74.

29. Pogoda JM, Preston-Martin S. Solar radiation, lip protection, and lip cancer risk in Los Angeles county women (California, United States). Cancer Cause Cont 1996;7:458-63.

30. Osterlind A. Cancer and UV-radiation. Pharmacol Toxicol 1993;72 suppl 1:67-8.

31. Fincham SM, Hanson J, Berkel J. Patterns and risks of cancer in farmers in Alberta. Cancer 1992;69:1276-85.

32. Pukkala E, Notkola V. Cancer incidence among Finnish farmers, 1979-93. Cancer Cause Cont 1997;8:25-33.

33. Milašin J, Puji N, Dedovi N, Nikoli , Petrovi V, Dimitrijevi $B$. High incidence of $\mathrm{H}$-ras oncogene mutation in squamous cell carcinoma of lip vermilion. J Oral Pathol Med 1994;23:298-301.

34. Heldaas SS, Langård S, Andersen A. Incidence of cancer in a cohort of magnesium production workers. $\mathrm{Br} \mathrm{J}$ Ind $\mathrm{Med}$
1989:46:617-23.

35. Dement JM, Hensley L, Kieding S., Lipscomb H. Proportionate mortality among union members employed at three Texas refineries. Am J Ind Med 1998;33:327 - 40.

36. Edling C, Friis L, Mikoczy Z, Hagmar L, Lindfors P. Cancer incidence among pharmacentical workers. Scand J Work Environ Health 1995;21:116-23.

37. Karlehagen S, Andersen A, Ohlson CG. Cancer incidence among creosote-exposed workers. Scand J Work Environ Health 1992;18:26-9.

38. Van Den Eeden SK, Friedman GD. Exposure to engine exhaust and risk of subsequent cancer. J Occup Med 1993;35:307-11.

39. Cassai E, Rotola A, Di Luca D, Manservig R, Meneguzzi G, Milanesi G, Califano A. Herpes simplex virus and human cancer, II: search for relationship between labial tumours and Herpes simplex type 1. Eur J Cancer 1981;17:695-702.

40. Blair A, Zahm SH. Agricultural exposures and cancer. Environ Health Perspect 1995;103 suppl 8:205-8.

41. Kristensen P, Andersen A, Irgens LM, Laake P, Bye AS Incidence and risk factors of cancer among men and women in Norwegian agriculture. Scand J Work Environ Health 1996;22:14-26.

42. Reif J, Pearce N, Fraser J. Cancer risks in New Zealand farmers. Int J Epidemiol 1989;18:768 - 74.

43. Spitzer WO, Hill GB, Chambers LW, Helliwell BE, Murphy HB. The occupation of fishing as a risk factor in cancer of the lip. New Engl J Med 1975;293:419—24.

44. Blomqvist G, Hirsh JM, Alberius P. Association between development of lower lip cancer and tobacco habits. J Oral Maxillofac Surg 1991;49:1044-9.

45. Pukkala E, Soderholm A, Lindqvist C. Cancer of the lip and oropharynx in different social and occupational groups in Finland. Oral Oncol Eur J Cancer 1994;30B:209-15.

46. Keller JE, Howe HL. Case-control studies of cancer in Illinois farmers using data from the Illinois State Cancer Registry and the US Census of Agriculture. Eur J Cancer 1994;30A:46973.

47. King GN, Healy CM, Glover MT, Kwan JT, Williams DM, Leigh IM, Worthington HV, Thornhil MH. Increased prevalence of dysplastic lip lesions in renal-transplant recipients. New Engl J Med 1995;332:1052-7.

Received for publication: 14 July 1998 